\title{
HUBUNGAN MUTASI PADA GEN LEPTIN EXON 2 DENGAN BOBOT LAHIR, PERTAMBAHAN BOBOT BADAN DAN BOBOT SAPIH SAPI BALI
}

\author{
(Association of Mutation on Exon 2 Leptin Gene With Birth Weight, Average Daily Gain And \\ Weaning Weight of Baliness Cattle)
}

\section{N. Hilmia, Rahmat D, dan Dudi}

Produksi Ternak Fakultas Peternakan Universitas Padjadjaran Jl. Raya Bandung Sumedang Km 21

Jatinangor Sumedang Jawa Barat, Indonesia

nena.hilmia@unpad.ac.id

Article Submitted : 26-01-2019

Article Accepted : 31-01-2019

\begin{abstract}
The one of genes that play an important role in the body metabolism that is closely related to productivity is the Leptin gene. This study aims to determine the assosiation polymorphism of exon 2 Leptin gene based on Single Nucleotide Polymorphism (SNP) with birth weight of Balinese cattle. This study used 47 DNA of Balinese cattle, their birth weight (BW), average daily gain (ADG) and yearling weight (YW) data, that were obtained from BPTU HPT Pulukan Bali. The isolation of DNA using a high salt concentrated method and DNA target was duplicated by PCR machine. Analysis genetic mutation of Leptin genes was performed by evaluating SNP in Exon 2 at $\mathrm{R} 25 \mathrm{C}$ and $\mathrm{R} 25 \mathrm{H}$, from direct sequencing results, using Bioedit and MEGA 5.2 program. The association of Leptin gene polymorphism with BW, ADG and YW were analyzed using variance analysis. The result showed that there were For genotypes based on SNP R25C and R25H, ie CC, CT, CA, and AA. There were no assosiation between Leptin gene polymorphism with birth weight $(\mathrm{BW})$, average daily gain (ADG) and yearling weight (YW) on Balinese cattle.
\end{abstract}

Key words : Bali cattle, Leptin gene, Productivity

\section{PENDAHULUAN}

Keragaman sumber daya genetik (SDG) sapi potong Indonesia perlu dieksplorasi untuk mengetahui keunggulan spesifik yang dimiliki dan bernilai ekonomis, dalam rangka mengembangkan SDG agar lebih bermanfaat bagi masyarakatnya. Fungsi utama sapi potong adalah sumber daging, sehingga eksplorasi potensi genetik diarahkan kepada identifikasi gen-gen yang mempengaruhi produktifitas.

Sapi Bali adalah sapi asli Indonesia, yang memiliki keunggulan seperti halnya sapi lokal, diantaranya dapat beradaptasi dengan input marginal, kemampuan reproduksi dan kualitas daging yang baik, seperti dikemukakan oleh Handiwirawan dan Subandryo (2004) bahwa kelebihan yang dimiliki sapi Bali, diantaranya fertilitas dan persentase karkas yang tinggi, kadar lemak daging yang rendah, dan mampu memanfaatkan pakan berkualitas rendah, serta memberikan respon cukup baik dalam perbaikan pakan. Keunggulan sapi Bali tersebut perlu digali lebih jauh dari sisi kemampuan genetik yang dimilikinya, yaitu gen-gen yang berkaitan dengan produktifitas. Keunggulan genetik perlu ditelusuri lebih dalam karena gen adalah pembawa sifat keturunan yang bersifat permanen, sehingga dapat dijadikan marka genetik/penanda 
genetik pada program pemilihan bibit sapi potong

Salah satu gen yang berperan penting dalam metabolisme tubuh yang erat kaitannya dengan produktifitas adalah gen Leptin. Beberapa hasil penelitian menunjukkan adanya korelasi positif antara keragaman gen leptin dengan parameter pertumbuhan. Salah satu parameter pertumbuhan yang penting dievaluasi sebagai dasar menilai produktifitas seekor ternak selama hidupnya adalah bobot lahir, pertambahan bobot badan dan bobot sapih, karena beberapa hasil penelitian menunjukkan ketiga parameter tersebut berimplikasi pada bobot akhir atau bobot potong. Hormon leptin adalah produk akhir dari gen obesitas, yang terlibat dalam berbagai proses fisiologis di dalam tubuh, yaitu mengatur asupan makanan, metabolisme energi pengaturan bobot badan, reproduksi dan kekebalan tubuh (Nkrumah et al. 2005 : Sáinz et al.). Perubahan sekuens gen leptin yang disebabkan mutasi pada sekuen nukleotide C1047T, menyebabkan perubahan pengkodean protein dari Arginin menjadi Sistein (Arg25Cys). Mutasi karena adanya substitusi cytosin oleh tymin pada sekuen tersebut adalah causative mutation, sehingga mempengaruhi fungsi fisiologis leptin dalam proses metabolisme (Kononof $e t$ al. 2005; Fortes et al. 2009). Selanjutnya hasil penelitian Hilmia, dkk (2015) gen leptin pada sapi lokal di Ciamis adalah polimorfik dengan ditemukannya mutasi Arg25C/R25C dan Arg25H/R25H.

Hasil penelitian Valūnienè et al (2007) pada manusia menunjukkan terdapat hubungan signifikan antara konsentrasi leptin dari plasenta dengan bobot lahir, semua parameter antropometri neonatal,dan beberapa faktor nutrisi induk. Selanjutnya hasil penelitian De vuyst et al (2010) membuktikan bahwa terdapat hubungan yang signifikan mutasi pada gen leptin exon 2 dengan bobot sapih. Sapi yang memiliki genotype CT dan TT karena adanya mutasi tersebut memiliki bobot sapih yang lebih tinggi dari genotype CC. Penelitian Woronuk et al (2012) melaporkan terdapat hubungan yang signifikan positif $(\mathrm{P}<$ 0,0001) antara genotype TT, CT dan CC dengan bobot badan, masing-masing sebesar $484.2 \pm 0.7,488.0 \pm 0.5$ and $487.3 \pm 0.6 \mathrm{~kg}$. Selanjutnya Selanjutnya Putra dkk (2017) menyatakan bahwa mutasi pada tingkat nukleotida (SNP) pada gen Leptin berpotensi dijadikan marka genetik berkaitan dengan peningkatan produktifitas pada sapi. Berdasarkan hal tersebut penelitian ini bertujuan untuk mengetahui hubungan keragaman gen Leptin Exon 2 berdasarkan SNP R25C dan R25H, dengan bobot lahir, pertambahan bobot badan harian $(\mathrm{PBBH})$ dan bobot sapih pada sapi Bali.

\section{METODE PENELITIAN}

\section{Materi Penelitian}

Materi penelitian ini adalah DNA yang diisolasi dari darah sapi Bali betina sebanyak 47 sampel, data bobot lahir, $\mathrm{PBBH}$ dan bobot sapih yang sudah dikoreksi terhadap 205 hari. Pengambilan sampel darah sapi Bali dan data lainnya diperoleh dari BPTU HPT sapi Bali Pulukan Denpasar.

\section{Metode Pengambilan Darah, Isolasi dan Visualisasi DNA}

Sampel darah diambil dari bagian leher (vena jugularis), menggunakan vaccutainer mengandung EDTA sebagai anti koagulan dan venoject. Isolasi DNA menggunakan metode konsentrasi garam pekat (High salt methode). Kuantifikasi dan pengujian kualitas DNA dianalisis dengan GenQuant spektrofotometer.

\section{Amplifikasi DNA Gen Leptin dan Penentuan genotype (genotyping)}

Perbanyakan DNA menggunakan mesin PCR, setiap pereaksi PCR dibuat volume $20 \mu$ dengan komposisi : 50 ng DNA template, PCR Kit Biolin atau Fermentas Green Taq, destilate water (DW) dan 0,1 $\mu \mathrm{M}$ primer $\mathrm{F} / \mathrm{R}$. Mesin PCR yang digunakan adalah gradien techne. Amplifikasi dimulai dengan denaturasi awal pada suhu $95^{\circ} \mathrm{C}$ 
selama 5 menit dilakukan satu kali, dilanjutkan dengan 35 kali denaturasi pada suhu $95^{\circ}$ selama 1 menit, annealing pada suhu $56^{\circ} \mathrm{C}$ selama 1 menit 13 detik dan ekstensi pada suhu $72^{\circ} \mathrm{C}$ selama 1 menit. Selanjutnya dilakukan ekstension lagi pada suhu $72^{\circ} \mathrm{C}$ selama 10 menit. Keragaman gen leptin dinalisis dengan melakukan sekuensing langsung dari produk PCR, yang dievaluasi menggunakan program Bioedit dan pensejajaran DNA menggunakan program MEGA 5.2, selanjutnya dianalisis posisi SNP nya dan dilakukan genotiping berdasarkan SNP R25C dan R25H.

\section{Parameter yang diukur}

1. Bobot Lahir (BL) : bobot badan pada saat lahir

2. Pertambahan Bobot Badan Harian (PBBH), dihitung berdasarkan pertambahan bobot badan harian dari lahir sampai umur 200 -279 hari.

PBBBH = bobot akhir - bobot lahir Lama pemeliharaan

3. Bobot sapih : bobot badan pada usia sapih (dikoreksi 205 hari)

\section{Analisis Data}

Hubungan keragaman gen Leptin dengan Bobot lahir PBBH dan bobot sapih dianalisis dengan analisis varians (Anova), dengan model matematika sebagai berikut:

$$
\mathrm{Y}_{\mathrm{ij}}=\mu+\alpha_{\mathrm{i}}+\mathrm{e}_{\mathrm{ij}}
$$

$Y_{i j} \quad=$ Bobot lahir, PBBH dan Bobot sapih

$\mu \quad=$ rata-rata

$\alpha_{\mathrm{i}} \quad=$ pengaruh genotipe ke $\mathrm{i}$

$\mathrm{e}_{\mathrm{ij}} \quad=$ Galat baku

\section{HASIL DAN PEMBAHASAN}

Keragaman gen leptin ditentukan berdasarkan adanya mutasi titik (point mutation) pada sekuen gen leptin posisi di exon 2 yaitu pada pengkodean asam amino ke 25 (Arginin). Mutasi titik yang terjadi merupakan mutasi yang penting karena mengubah pengkodean asam amino Arginin menjadi Cystein dan Histidin yang diduga dapat mengubah fungsi dari hormon leptin sebagai produk akhir dari gen leptin. Berikut adalah hasil pensejajaran sekuen nukleotide dan genotyping gen leptin pada sapi Bali.

EU313203.1_Bos_indicus_leptin

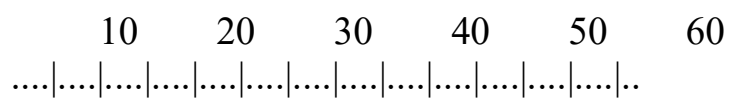

TTTGGCC $\overline{\mathbf{C}}$ TAT $\mathbf{T}$ TGT $\overline{\mathbf{C}}$ TTA $\overline{\boldsymbol{C}}$ TTGGAGGCTGTGCCCATCCGCAAGGTCCAGGAT GACACCAAAACCC

Sapi Bali 3 Alel T

Sapi Bali 4 Alel A

Sapi Bali 6 Alel A

Sapi Bali 9 Alel C

Sapi Bali 18 Alel T

Sapi Bali 19 Alel C

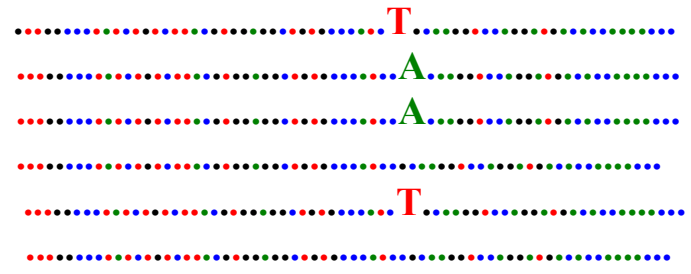

Gambar 1. Penentuan alel berdasarkan SNP R25C (Arg25Cys/C1047T) dan R25H Arg25His/G1048A dari hasil pensejajaran (allignment) sekuen nukleotide gen Leptin Exon 2

Salah satu parameter produktivitas yang penting dievaluasi dalam pengelolaan pembibitan sapi potong adalah bobot lahir (BL) karena berkorelasi positif dengan bobot sapih dan bobot dewasa. Pedet yang memiliki BL besar dapat diduga akan mempunyai pertambahan bobot badan yang lebih tinggi, sehingga dapat mencapai berat sapih dan berat akhir yang tinggi. Berikut 
adalah hasil penelitian pengaruh keragaman gen leptin terhadap BL, PBBH dan BS.

Tabel 1. Hubungan Keragaman Gen Leptin dengan Bobot Lahir, PBBH dan Bobot sapih Pada Sapi Bali

\begin{tabular}{lcccc}
\hline \multirow{2}{*}{ Parameter } & \multicolumn{4}{c}{ Genotip } \\
\cline { 2 - 5 } & $\mathrm{CC}$ & $\mathrm{CT}$ & $\mathrm{CA}$ & $\mathrm{AA}$ \\
\hline \multicolumn{1}{c}{ Rataan $(\mathrm{kg})$} & $\mathrm{n}=9$ & $\mathrm{n}=7$ & $\mathrm{n}=5$ & $\mathrm{n}=26$ \\
\hline Bobot Lahir & $19,22 \pm 1,09$ & $19,40 \pm 4,33$ & $19,14 \pm 2,19$ & $18,88 \pm 1,99$ \\
PBBH & $0,33 \pm 0,07$ & $0,33 \pm 0,11$ & $0,35 \pm 0,07$ & $0,27 \pm 0,07$ \\
Bobot sapih & $84,28 \pm 14,90$ & $87,41 \pm 12,77$ & $84,71 \pm 21,92$ & $72,08 \pm 14,67$ \\
\hline
\end{tabular}

Keterangan $\mathrm{PBBH}=$ Pertambahan bobot badan harian

Pada penelitian ini rata-rata BL sapi Bali betina relatif lebih tinggi dengan hasil penelitian Prasojo dkk (2008) menggunakan data bobot lahir sapi Bali betina hasil Inseminasi Buatan sebanyak 799 data dari tahun 1997 sampai dengan 2003 di pulau Bali, bobot lahirnya sebesar 17,9 $\pm 1,6 \mathrm{~kg}$. Selanjutnya hasil penelitian Kaswati dkk (2013) di tempat penelitian yang sama dengan penelitian ini, menggunakan 150 data yang sudah dikoreksi terhadap jenis kelamin adalah sebesar 17,8 $\pm 1,08 \mathrm{~kg}$. Berdasarkan data tersebut terdapat peningkatan BL sapi Bali di BPTU HPT Pulukan pada kurun waktu 2013 - 2017. Berdasarkan hal tersebut, diduga terjadi peningkatan mutu genetik, karena sebagai balai pengembangan dan pembibitan BPTU HPT menjalankan program breeding yang cukup intensif, selain itu adanya perbaikan manajemen dalam kurun waktu tersebut.

Pertambahan bobot badan harian merupakan parameter penting dalam pemeliharaan sapi potong karena bernilai ekonomis. Nilai PBBH pada penelitian ini relatif lebih besar dari penelitian Wirdahayati (2010) yang menyatakan pertumbuhan kelompok sapi betina umur $<1$ tahun yang dipelihara di padang penggembalaan di pulau Timor pada musim hujan sebesar 0,09 kg/ekor/hari. Apabila dilakukan penyapihan dini pada musim kemarau sebesar $0,27 \mathrm{~kg}$ dan sapi kontrol
PBB nya hanya $0,08 \mathrm{~kg} /$ ekor/hari. Selanjutnya hasil penelitian Riswandi et al (2015) PBBH sapi Bali yang diberi pakan dengan dan tanpa tambahan Lamtoro sampai dengan $30 \%$ berkisar antara $0,32 \pm 0,04$ $\mathrm{kg} /$ ekor/hari sampai dengan $0,61 \pm 0,13$ $\mathrm{kg} /$ ekor/hari, lebih tinggi dari hasil penelitian ini.

Bobot sapih sapi Bali pada penelitian ini relative lebih rendah dari bobot sapih sapi Bali hasil penelitian Suranjaya, dkk. (2010) bahwa rataan bobot sapih sapi bali pada kisaran umur 160-250 hari di Proyek Pembibitan dan Pengembangan sapi Bali (P3Bali) diperoleh sebesar 97,42 $\pm 5,28 \mathrm{~kg}$. Perbedaan BL, PBBH dan Bobot sapih pada sapi Bali, dapat disebabkan adanya variasi genetik sapi Bali, lokasi penelitian yang berbeda, perbedaan manajemen pemeliharaan dan pakan yang digunakan serta pengaruh lingkungan lainnya, serta jumlah data yang digunakan.

Tabel 3 menunjukkan tidak terdapat perbedaan yang nyata $(\mathrm{P}>0,05)$ bobot lahir, PBBH dan bobot sapih diantara kelima genotipe gen leptin berdasarkan SNP R25C (Arg25Cys/C1047T) dan R25H Arg25His/G1048A. Hasil penelitian ini sejalan dengan hasil penelitian Lusk et al (2007) menyatakan SNP R25C SNP tidak mempengaruhi secara nyata pada parameter pertumbuhan, seperti halnya pertambahan bobot badan. Kononof et al. (2014) yang 
mengemukakan bahwa perbedaan genotipe berdasarkan SNP Arg25Cys/ R25C pada gen Leptin exon 2, tidak berpengaruh nyata pada bobot badan awal dan akhir (initial and final body weight).

Selanjutnya hasil penelitian Kononof et al. (2017) menunjukkan . SNP pada gen leptin banyak berkontribusi pada sifat yang berkaitan dengan pembentukan lemak, mutasi pada asam amino R25C mempengaruhi lemak pada urat daging mata rusuk, persentase lemak intramuskuler (IMF). Shin dan Chung (2007) melaporkan bahwar pada sapi Korea, SNP C1180T pada gen leptin berpotensi digunakan sebagai penanda genetik untuk sifat karkas dan kualitas daging berdasarkan adanya hubungan yang signifikan antara SNP dengan tebal lemak punggung, dengan skore marbling, sapi dengan genotip CC memiliki lemak punggung dan skor marbling yang lebih tinggi dari genotype CT danTT. Selanjutnya penelitian Woronuk et al (2012) melaporkan terdapat hubungan yang signifikan positif $(\mathrm{P}<0.0001)$ antara frekuensi alel $\mathrm{T}$ dan ketebalan lemak punggung, pada sapi yang bergenotipe TT memiliki lemak punggung yang lebih tinggi dibandingkan genotipe CT dan CC.

Berdasarkan hasil penelitian ini dan penelitian sebelumnya diduga bahwa gen leptin berkaitan dengan pertumbuhan atau deposisi lemak. Beberapa hasil penelitian mengemukakan bahwa SNP pada gen leptin exon 2 berkontribusi pada pertumbuhan lemak, seperti berkaitan dengan kualitas lemak karkas, ketebalan lemak punggung dan deposisi lemak (DeVuyst 2010; Kononof et al. 2014). Parameter pada pada penelitian adalah BL, PBBH sampai dengan umur 200 - 279 hari dan BS, pada periode diatas pertumbuhan lemak masih rendah, sehingga diduga ekspresi gen Leptin dalam bentuk hormone leptin belum maksimal karena lemak yang belum terdeposisi belum optimal. Warriss (2000) menyatakan bahwa deposisi lemak pada sapi membentuk fungsi linier antara umur dan waktu, persentase lemak tubuh meningkat pada saat ternak dewasa dan struktur lain (tulang dan otot) berhenti bertumbuh.

\section{KESIMPULAN}

Hasil penelitian menunjukkan pada sapi Bali tterdapat empat genotip yaitu $\mathrm{CC}$, $\mathrm{CT}, \mathrm{CA}$, dan AA berdasarkan mutasi titik yang mengubah asam amino Arginin menjadi Cystein (R25C) dan Histidin (R25H). Tidak terdapat hubungan antara keragaman genetik pada gen leptin dengan bobot lahir, pertambahan bobot badan harian dan bobot sapih pada sapi Bali.

\section{DAFTAR PUSTAKA}

DeVuyst EA. 2010. The Economics of Gene Testing Cattle. Oklahoma Cooperative Extension Service. [Internet]. Diunduh 2011 Nov 8. Tersedia pada: http://osufacts.okstate.edu.

Fortes MRS, Curi RA, Chardulo LAL, Silveira AC, Assumpção MEOD, Visintin JA, and de Oliveira HN. 2009. Bovine gene polymorphisms related to fat deposition and meat tenderness. Genet and Mol Biol. 32(1):75-82.

Handiwirawan dan Subandryo. 2004. Potensi dan keragaman sumberdaya genetik sapi Bali. WARTAZOA Vol. 14 No. 3.

Hilmia, N, R.R. Noor, C. Sumatri, R. Priyanto dan E. Gurnadi. 2013. Karakterisasi Fenotipe dan Potensi Genetik Serta Hubungannya Dengan Produktivitas Dan Kualitas Daging Sapi Lokal Di Ciamis Jawa Barat. Disertasi. Institut Pertanian Bogor. Bogor

Kaswati, Sumadi, dan Nono Ngadiyono. 2013. Estimasi Nilai Heritabilitas Berat Lahir, Sapih, Dan Umur Satu Tahun Pada Sapi Bali Di Balai Pembibitan 
Ternak Unggul Sapi Bali. Buletin Peternakan Vol. 37(2): 74-78

Kononoff PJ, Deobald HM, Stewart EL, Laycock AD and Marquess FLS. 2005. The effect of a leptin single nucleotide polymorphism on quality grade, yield grade, and carcass weight of beef cattle. J Anim Sci. 83:927-932.

Kononoff PJ, Defoor PJ, Engler MJ, Swingle RS, James ST and Marquess FLS. 2014. Impact of a leptin single nucleotide polymorphism and ractopamine hydrochloride on growth and carcass characteristics in finishing steers. J. Anim. Sci..92:2702-2707.

Kononoff, P.J, P.J. Defoor, M.J. Engler, J.F. Gleghorn, R.S. Swingle, S.T. James, and F.L.S. Marquess. 2017. Impacts of a leptin SNP on growth performance and carcass characters in finishing steers studied over time. J. Anim. Sci. 95(1):194-200.

Lusk JL. 2007. Association of single nucleotide polymorphisms in the leptin gene with body weight and backfat growth curve parameters for beef cattle. $J$ Anim Sci. 85:1865-1872. doi: 10.2527/jas.2006-665.

Nkrumah JD, Li C, Yu J, Hansen C, Keisler DH, and Moore SS. 2005 Polymorphisms in the bovine leptin promoter associated with serum leptin concentration, growth, feed intake, feeding behavior, and measures of carcass merit. J Anim Sci. 83:20-28.

Prasojo G, Arifiantini I Dan Mohamad K. 2008. Korelasi Antara Lama Kebuntingan, Bobot Lahir Dan Jenis Kelamin Anak Hasil Inseminasi Buatan Pada Sapi Bali Prosiding Seminar Nasional Teknologi Peternakan dan Veteriner : 65-70.
Putra WPB dan Indriastuti RR. 2017. Gen Leptin sebagai Gen Potensial untuk Seleksi Molekuler pada Sapi di Indonesia. Wartazoa ; 27 No. 3 : 105116 DOI: http://dx.doi.org/10.14334/wartazoa.v $\underline{27 \mathrm{i} 3.1579}$

Sáinz, N, J. Barrenetxe, M.J. MorenoAliaga, and J.A. Martínez. Leptin resistance and diet-induced obesity: central and peripheral actions of leptin. J. Metab. Clin and exp. 64: 35-46. (2015).

Shin S.C., and E. R. Chung. 2007. Association of SNP Marker in the Leptin Gene with Carcass and Meat Quality Traits in Korean Cattle. AsianAust. J. Anim. Sci. Vol. 20, No. $1: 1$ 6.

Suranjaya Ig, Ardika IN, dan Indrawati, RR. 2010. Faktor-Faktor Yang Mempengaruhi Produktivitas Sapi Bali Di Wilayah Binaan Proyek Pembibitan Dan Pengembangan Sapi Bali Di Bali. Majalah Ilmiah Peternakan : 13 No. 3 :83-87.

Riswandi, Ali AIM, Muhakka, Y. Syaifudin, and I. Akbar. 2015. Nutrient Digestibility and Productivity of Bali Cattle Fed Fermented Hymenachne amplexia calis Based Rations Supplemented with Leucaena leucocephala. Media Peternakan 38(3):156-162

Warris PD. 2000. Meat Science. An Introductory Text. New York (US) : CABI Publishing.

$\begin{array}{ccr}\text { Wirdahayati R.B. } & 2010 . & \text { Penerapan } \\ \text { Teknologi } & \text { Dalam } & \text { Upaya } \\ \text { Meningkatkan } & \text { Produktivitas Sapi } \\ \text { Potong Di Nusa } & \text { Tenggara Timur } \\ \text { Wartazoa: } 20 . \text { No. } 1: 12-20 .\end{array}$


Valūnienė M, Verkauskienė R, Boguszewski M, Dahlgren J, Lašienè D, Lašas L, Wikland KA. 2007. Leptin levels at birth and in early postnatal life in smalland appropriate-for-gestational-age infants. Medicina (Kaunas); 43(10): 784-791.
Woronuk GN, Marquess FL. James ST, Palmer J, Berryere T, Deobald $\mathrm{H}$, Howie S. and Kononoff PJ. 2012. Association of leptin genotypes with beef cattle characteristics. [Short Communication]. Anim. Genet. 1-3. doi: $10.1111 /$ j. $1365-2052.2012 .02320$ 